\title{
SECRETARY-TREASURER'S REPORT, 1942.
}

It is remarkable to report that during the year 1942, the activities of the Society were not more radically curtailed as a result of the great pressure of work engaging the attention of the members. This has meant that the members have had to "steal" time from their sleep in order to give attention to Society matters.

The membership at the close of the year numbered 445 . The 445 members are classified as follows: (a) Full members, 422; (b) Affiliates, 14; (c) Honorary, 9. The names of the 13 new members are as follows: Dr. C. E. Atwood, A. S. Bray, D. W. Colwell, C. B. Dunham, K. Graham, G. Guay, R. S. Jones, Prof. John E. Liersch, J. S. Mottishaw, G. H. Murchison, W. E. McGraw, Norman Ross, and Ralph E. Smith.

The 16 members written off the rolls in 1942 were classified as follows: Resignations, 4; Non-Payment of Dues, 10; Deaths, 2.

I regret to report the death of $\mathrm{L}$. McIntosh Ellis, former Director of Forests for New Zealand, in December, 1941. As I was not informed of Mr. Ellis death at the time of my last year's report, no mention was made of it. I regret also to report the death of Robert Heggie, Pilot Officer with the R.C.A.F. who was reported missing on Air Operations at the beginning of April, 1942, and later reported dead on July 7, 1942. Mr. Heggie is, according to my records, the first member of the C.S.F.E. to lose his life in combat in the present war.

The General Executive Committee for 1943 is composed as follows: President-J. D. B. Harrison; Vice-President-R. M. Brown; Immediate PastPresident-L. S. Webb; Section Representatives-Maritimes, B. W. Flieger; Ottawa Valley, S. H. Francis; Southern Ontario, J. C. W. Irwin; Northern Ontario, H. C. Walkom; Northwestern Ontario, P. Addison; Prairies, G. Tunstell; Vancouver, R. M. Brown; Victoria, A. P. MacBean.

I would remind you that by letter ballot adopted December 31, 1942, J. D. B. Harrison and R. M. Brown were voted to office for a two year term, until December, 1944.

I wish to report that the letter ballot with respect to the increase of $\mathrm{Mem}$ bership Fees to Seven Dollars was passed by over a two-thirds majority and has, therefore, been incorporated into the Constitution. Article V, Section 2 of the Constitution respecting arrears in fees has been amended as a result of a letter ballot and now members who are in arrears for one year are suspended, instead of being carried for a two-year period as heretofore.

With regard to finances, I am pleased to report that the operating revenue for the year exceeded the operating expenditure by $\$ 28.44$ net.

The Forest Policy Committee is to be commended and heartily thanked by the Society for the excellent statement which it prepared for voting.

The Research Sub-Committees have also earned the thanks of the Society for the submission of their reports.

The Committee on Post-war Rehabilitation has submitted a report to the General Executive Committee at this meeting.

Respectfully submitted,

(Signed) A. R. Fenwick, Secretary-Treasurer. 
Revenue:

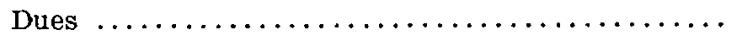

Chronicle subscriptions $\ldots \ldots \ldots \ldots \ldots \ldots \ldots$

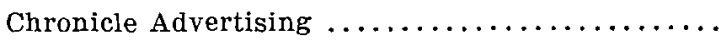

Receipts from Reprints ............. \$72.04

Less: Cost of Reprints ........... 63.52

Sundry Revenue $\ldots \ldots \ldots \ldots \ldots \ldots \ldots \ldots$ -

$\$ 1,882.48$

538.35

8.52

20.78

Total Revenue

$\$ 2,532.12$

EXPENDITURE:

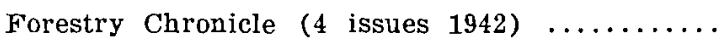

Executive Honoraria-Secretary Treasurer ......

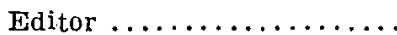

Office Salaries $\ldots \ldots \ldots \ldots \ldots \ldots \ldots \ldots \ldots \ldots \ldots$

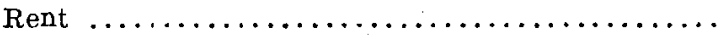

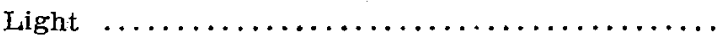

Supplies $\ldots \ldots \ldots \ldots \ldots \ldots \ldots \ldots \ldots \ldots \ldots \ldots \ldots$

Equipment $\ldots \ldots \ldots \ldots \ldots \ldots \ldots \ldots \ldots \ldots \ldots \ldots$

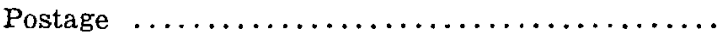

Telephone and Telegraph $\ldots \ldots \ldots \ldots \ldots \ldots \ldots$

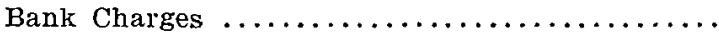

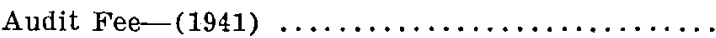

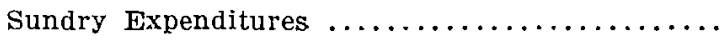

Empire Folestry Association Dues .............

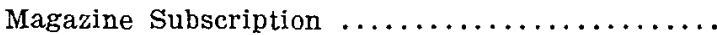

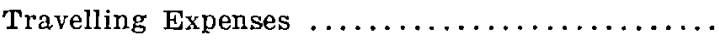

Annual Meeting Expenditure . . . . . . . . $\$ 180.10$

Less: Annual Meeting Revenue ..... 102.95

$\$ 827.51$

250.00

225.00

453.05

180.00

9.60

48.22

35.48

105.55

16.70

6.09

10.00

141.08

10.00

8.25

100.00

77.15

TOTAT EXPENDTTURE

SCHLICH MEMORIAL TRUST FUND

Balance-December 31st, $1941 \ldots \ldots \ldots \ldots \ldots \ldots \ldots$

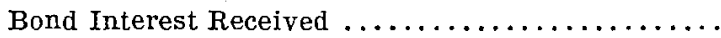

$\$ \quad 18.16$

Bank Interest Received

12.00

Less: Withdrawal for Prizes 
BALANCE SHEET

DECEMBER 31, 1942.

Asseits:

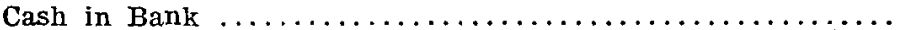

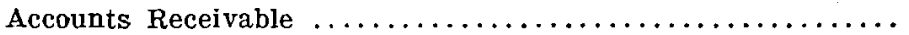

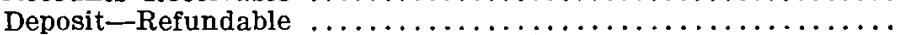

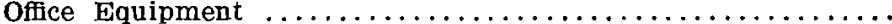





$\$ 242.98$

26.81

4.00

61.30

7.00

1.00

$\$ 343.09$

LLABMITIES:

Chronicle Subscriptions in advance-1943

Dues Paid in advance-1943.

1942 .

Less: AdjustmentsTransfer Schlich Memorial Fund from General Account. Depreciation on Office Equipment ................... Sundry Adjustments of Accounts Receivable and office Supplies .................

To set Up Prepaid Dues-1943

Add: Net Surplus for Year 1942..

APPRoveD-(Signed) A. R. FENwICK Secretary-Treasurer.

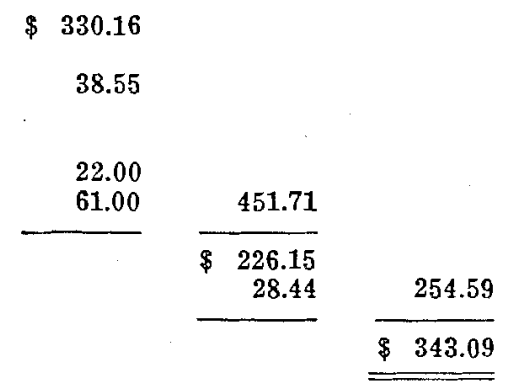

$\$ 27.50$ 61.00

$\$ 88.50$

Toronto, February 24th, 1943.

To the Members of the Canadian Society of Forest Engineers:

The form of your annual statement has been changed for 1942 with a view of presenting a clearer picture of the year's operations and in order that the Surplus Account may be readily reconciled from year to year. However, the figures are those approved at the Annual Meeting.

$I$ have examined the records of your Society for the year ended December 31st, 1942, and I certify that in my opinion the accompanying Balance Sheet, Revenue and Expenditure and Trust Fund Statements are drawn up in accordance with accepted accounting principles so as to exhibit a true and correct view of the year's operations and the financial position of the Society according to the best of my information, the explanations given me and as shown by the books.

(Signed) ROBERT G. THOMSON, Certified Public Accountant. 